\title{
Pulmonary Hypertension for Clinicians: Time to Call on Genetics?
}

\author{
Frank Reichenberger \\ Pulmonary Vascular Disease Unit, University Giessen Lung Center, University Hospital Giessen, Giessen, Germany
}

Over the last decade, pulmonary hypertension has developed from a largely unknown disease to a very well recognised disorder. During this period, three world conferences have been held addressing pathobiology, diagnosis, and treatment of the disease. Currently, we classify approximately 30 different forms of pulmonary hypertension. The early recognition of a hereditary type of pulmonary arterial hypertension (PAH) was suggestive of a genetic cause of the disease. Basic research has revealed genetic alterations in the TGF- $\beta$ system to be involved in the pathogenesis of PAH. Among the TGF- $\beta$ superfamily, a mutation in the bone morphogenetic protein receptor 2 (BMPR2) has been linked to PAH, leading to an altered intracellular signalling with subsequent proliferation of smooth muscle cells and increased endothelial cell apoptosis in the pulmonary vasculature. Epidemiological studies have shown a high frequency of BMPR2 mutation in hereditary PAH (70\%) and idiopathic PAH (20\%), rarely in $\mathrm{PAH}$ associated with congenital heart disease and ingestion of appetite suppressants, but so far not in other forms of pulmonary hypertension. Patients carrying a BMPR2 mutation are known to have an earlier onset of the disease and are less likely to show an acute vasodilator response [1]. Furthermore, healthy relatives of PAH patients, who carry the identical BMPR2 mutation, exhibit a higher proportion of hypertensive pulmonary ar- tery pressure response to exercise and hypoxia, an early indicator of altered pulmonary vascular function [2].

The pathogenesis of $\mathrm{PAH}$ is complex and involves a variety of cellular and molecular mechanisms, including the serotonin- and nitric oxide system. Therefore, genetic modifiers have been suggested to be involved in the development of PAH [3].

Are genetic changes relevant in our current clinical management of pulmonary hypertension?

In the current issue of Respiration, Ulrich et al. [4] describe genetic changes in patients with idiopathic PAH and chronic thromboembolic pulmonary hypertension (CTEPH) who were referred to the pulmonary hypertension centre in Zürich (Switzerland). They performed extensive genetic studies including the analysis of the BMPR2 gene, and polymorphisms in a variety of genes involved in the serotonin and nitric oxide pathway. Additionally, they investigated patients with distinct left heart disease but without pulmonary hypertension. The authors did not find any difference in the genetic analysis between patients with CTEPH, idiopathic PAH or left heart disease. However, they detected a BMPR2 mutation in a patient with coronary artery disease without $\mathrm{PAH}$ or a family history of PAH. Furthermore, different polymorphisms of the BMPR2 gene were either present in $\mathrm{PAH}$, or in CTEPH or in both. PAH patients carrying a

\section{KARGER}

Fax +4161306 1234

E-Mail karger@karger.ch

www.karger.com
(C) 2009 S. Karger AG, Basel

0025-7931/10/0794-0274\$26.00/0

Accessible online at:

www.karger.com/res
Dr. med. Frank Reichenberger

Pulmonary Vascular Disease Unit, University Giessen Lung Center

University Hospital Giessen, Klinikstrasse 36

DE-35390 Giessen (Germany)

E-Mail frank.reichenberger@innere.med.uni-giessen.de 
certain polymorphism of the BMPR2 gene presented with a lower exercise capacity at initial assessment.

Limited to a small single-centre study, the authors present their 'real-life experience' of genetic testing in patients with pulmonary hypertension. The authors support the impression that patients with alterations in the BMPR2 gene might have a less favourable course of the disease. This study might provide data to assess the relevance of different sequence variants of the BMPR2 gene in either CTEPH or PAH in the long-term follow-up. The presence of a BMPR2 mutation in a patient with coronary artery disease without phenotype of family history of
PAH could indicate that BMPR2 mutation is not exclusively linked to PAH. However, this patient should be closely followed up [4].

Currently, we should inform our patients about the possible familiar trait of the disease, advise the regular screening of family members, and consider pulmonary hypertension at the presence of symptoms in relatives [2, 5]. So far, genetics has not yet reached everyday clinical practise for patients with pulmonary hypertension; however, clinicians should keep a watchful eye on further developments in this rapidly evolving field. The presented study might be a basis to provide answers in future.

\section{References}

1 Machado RD, Eickelberg O, Elliott CG, Geraci MW, Hanaoka M, Loyd JE, Newman JH, Phillips JA 3rd, Soubrier F, Trembath RC, Chung WK: Genetics and genomics of pulmonary arterial hypertension. J Am Coll Cardiol 2009;54:S32-S42.

2 Grünig E, Weissmann S, Ehlken N, Fijalkowska A, Fischer C, Fourme T, Galié N, Ghofrani A, Harrison RE, Huez S, Humbert M, Janssen B, Kober J, Koehler R, Machado RD, Mereles D, Naeije R, Olschewski H, Provencher S, Reichenberger F, Retailleau K, Rocchi G, Simonneau G, Torbicki A, Trembath R, Seeger W: Stress Doppler echocardiography in relatives of patients with idiopathic and familial pulmonary arterial hypertension: results of a multicenter European analysis of pulmonary artery pressure response to exercise and hypoxia. Circulation 2009;119:1747-1757.
3 Morrell NW, Adnot S, Archer SL, Dupuis J, Jones PL, MacLean MR, McMurtry IF, Stenmark KR, Thistlethwaite PA, Weissmann N, Yuan JX, Weir EK: Cellular and molecular basis of pulmonary arterial hypertension. J Am Coll Cardiol 2009;54:S20-S31

4 Ulrich S, Szamalek-Hoegel J, Hersberger M, Fischler M, Garcia JS, Huber LC, Grünig E, Janssen B, Speich R: Sequence variants in $B M P R 2$ and genes involved in the serotonin and nitric oxide pathways in IPAH and CTEPH: relation to clinical parameters and comparison with left heart disease. Respiration 2010;79:279-287.
5 Galiè N, Hoeper MM, Humbert M, Torbicki A, Vachiery JL, Barbera JA, Beghetti M, Corris P, Gaine S, Gibbs JS, Gomez-Sanchez MA, Jondeau G, Klepetko W, Opitz C, Peacock A, Rubin L, Zellweger M, Simonneau G: Guidelines for the diagnosis and treatment of pulmonary hypertension: the Task Force for the Diagnosis and Treatment of Pulmonary Hypertension of the European Society of Cardiology (ESC) and the European Respiratory Society (ERS), endorsed by the International Society of Heart and Lung Transplantation (ISHLT). Eur Heart J 2009; 30:2493-2537. 